Instytut Archeologii

Uniwersytet Mikołaja Kopernika w Toruniu

\title{
Stawomir Wadyl
}

\section{WCZESNOŚREDNIOWIECZNA CERAMIKA NACZYNIOWA Z MEZOREGIONU DORZECZA GÓRNEJ DRWĘCY}

Zarys treści. W artykule zaprezentowano wyniki wieloaspektowej analizy wczesnośredniowiecznych materiałów ceramicznych z mezoregionu dorzecza górnej Drwęcy. Pozyskano je podczas badań weryfikacyjnych prowadzonych na wczesnośredniowiecznych grodziskach w Domkowie, Lipowcu, Morlinach, a także Ornowie-Lesiaku. Zbiór analizowano w aspekcie techniczno-technologicznym, morfologicznym, a także stylistycznym. Uzyskane wyniki oraz związki chronologiczno-przestrzenne w ramach tej kategorii źródeł dały podstawy do określenia chronologii procesów zasiedlenia zachodzących we wczesnym średniowieczu na obszarze dorzecza górnej Drwęcy.

Słowa kluczowe: wczesne średniowiecze, ceramika naczyniowa, grodzisko wczesnośredniowieczne, pogranicze mazowiecko-pruskie, osadnictwo.

\section{Zagadnienia wstępne}

Materiały źródłowe będące podstawą niniejszego opracowania zostały pozyskane podczas dwóch sezonów badań prowadzonych w latach 2011-2012 przez ekspedycję Instytutu Archeologii Uniwersytetu Mikołaja Kopernika w Toruniu1. W 2011 roku prowadzono prace na grodziskach w Ornowie-Lesiaku (gm. Ostróda, stanowisko 3) i Domkowie (gm. Grunwald, stanowisko 1), w 2012 roku kontynuowano je na grodzisku w Ornowie-Lesiaku; ponadto włączono do programu badań jeszcze dwa grodziska z okolic Ostródy - w Lipowcu (stanowisko 1) oraz w Morlinach (stanowisko 1) (ryc. 1). Wśród

\footnotetext{
${ }^{1}$ Badania prowadzono w ramach projektu badawczego pt. „Pogranicze słowiańsko-bałtyjskie we wczesnym średniowieczu (badania weryfikacyjno-sondażowe wybranych grodzisk oraz weryfikacja materiałów ceramicznych" (grant WNH nr 329-NH), kontynuowanego w 2012 roku jako „Pogranicze słowiańsko-bałtyjskie we wczesnym średniowieczu (badania weryfikacyjno-sondażowe wybranych stanowisk oraz weryfikacja materiałów z badań AZP)" (grant WNH nr 1008-NH). Rezultaty tych badań zostały opublikowane w odrębnym artykule (Wadyl 2013).
} 


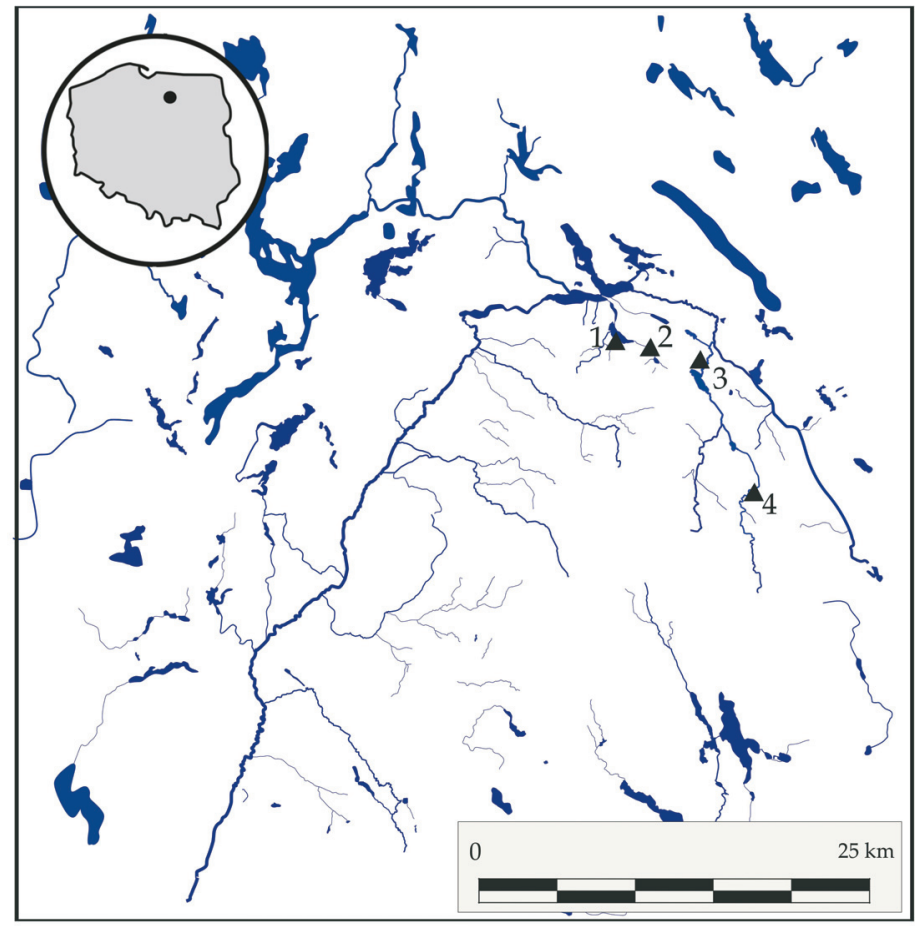

Ryc. 1. Lokalizacja badanych grodzisk z dorzecza górnej Drwęcy. 1 - Morliny, gm. Ostróda, stanowisko 1; 2 - Ornowo-Lesiak, gm. Ostróda, stanowisko 3; 3 - Lipowiec, gm. Ostróda, stanowisko 1; 4 - Domkowo, gm. Grunwald, stanowisko 1 (rys. S. Wadyl)

Fig. 1. Distribution of the excavated hill forts of the Upper Drwęca basin. 1 - Morliny, comm. Ostróda, site 1; 2 - Ornowo-Lesiak, comm. Ostróda, site 3; 3 - Lipowiec, comm. Ostróda, site 1; 4 - Domkowo, comm. Grunwald, site 1 (drawn by S. Wadyl)

pozyskanych z badań 746 fragmentów naczyń wyróżniono 18 zespołów ceramicznych posiadających zróżnicowane walory poznawcze; zaliczono je do czterech kategorii: $\mathrm{R}^{4}-\mathrm{R}^{1}$ (ryc. 2) ${ }^{2}$. Tylko jeden zespół (Ornowo-Lesiak 3/2) uznano za reperowy (kategoria $\mathrm{R}^{4}$ ), trzy (Ornowo-Lesiak 3/8, Ornowo-Lesiak 3/9, Domkowo 1/4) miały duże walory poznawcze (kategoria $\mathrm{R}^{3}$ ), jednak zdecydowana większość niewielkie (kategorie $\mathrm{R}^{2}$ i $\mathrm{R}^{1}$ ).

Najliczniejszy, a zarazem najbardziej wartościowy pod względem poznawczym zbiór materiałów ceramicznych pochodził z badań prowadzonych

${ }^{2}$ Wydzielono cztery podstawowe kategorie poznawcze, uwzględniając ich najistotniejsze cechy. Zasadnicze znaczenie dla proponowanego podziału miała liczebność zespołu, liczba całych bądź rekonstruowanych do największej wydętości brzuśca naczyń, sposób pozyskania oraz warunki depozycji i stan zachowania. 


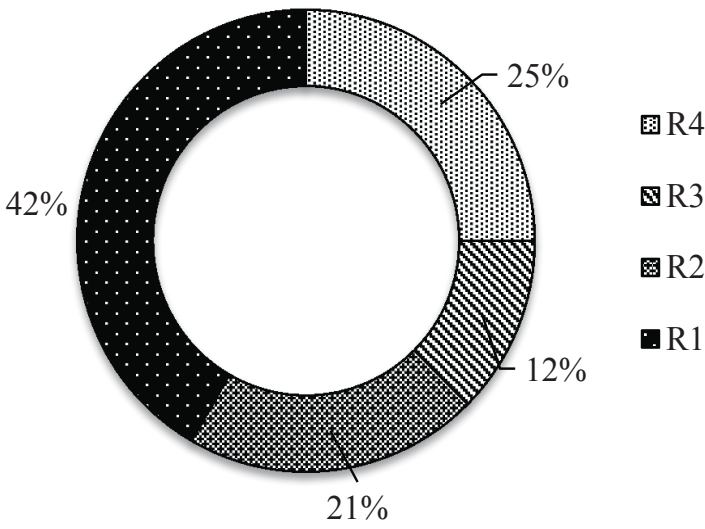

Ryc. 2. Mezoregion górnej Drwęcy. Zestawienie procentowe zespołów ceramicznych (oprac. S. Wadyl)

Fig. 2. Upper Drwęca Mesoregion. Percentage share of pottery assemblages (elab. by S. Wadyl)

na grodzisku w Ornowie-Lesiaku, wydobyto go z dwóch ziemianek (wykopy 1/2011 i 1/2012) odsłoniętych w strefie przywałowej (zespoły Ornowo-Lesiak $3 / 2$ oraz Ornowo-Lesiak 3/8). Przeważały w nim fragmenty naczyń całkowicie obtaczanych (GT V - około 85\%), pozostałe pochodziły z egzemplarzy ręcznie lepionych (GT I) oraz częściowo obtaczanych (GT II, GT III) (ryc. 3).

W sąsiedztwie ziemianki odkrytej w wykopie 1/2012 natrafiono na obiekt z konstrukcją kamienną, z którego także pozyskano materiały o znacznej wartości poznawczej (zespół Ornowo-Lesiak 3/9). Charakteryzowały się one również przewagą fragmentów naczyń całkowicie obtaczanych (GT $\mathrm{V}-83,5 \%$ ), znacznie mniej było ułamków egzemplarzy obtaczanych do największej wydętości brzuśca (GT III - 16,5\%). Pozostałe zespoły ceramiczne $\mathrm{z}$ tego stanowiska nie posiadały większej wartości poznawczej z powodu niewielkiej ich liczebności.

Na grodzisku w Domkowie najbardziej wartościowy zespół odkryto w obrębie bruku kamiennego, na który natrafiono w wykopie usytuowanym na styku majdanu i wewnętrznego stoku wału w południowej części obiektu (Domkowo 1/4). Przeważały w nim ułamki naczyń ceramicznych całkowicie obtaczanych (GT V - 55\%), jednak znaczny odsetek stanowiły fragmenty wyrobów ręcznie lepionych, obtaczanych przykrawędnie (GT II - 40\%), niewielki zaś obtaczanych do największej wydętości brzuśca (GT III - 5\%). $\mathrm{W}$ wykopie wytyczonym $\mathrm{w}$ miejscu suchej fosy, z nawarstwień związanych z rozwaliskiem kamiennym, wydobyto nieliczne ułamki naczyń całkowicie obtaczanych (GT V - 9 ułamków). 
Zespoły ceramiczne o mniejszej wartości poznawczej (kategorii $\mathrm{R}^{1}$ ) pozyskano między innymi w trakcie badań powierzchniowych przeprowadzonych na pobliskiej osadzie przygrodowej (Domkowo 2/1). Liczył on 150 ułamków naczyń, głównie całkowicie obtaczanych (GT V - 80\%), w pozostałej części obtaczanych do największej wydętości brzuśca (GT III - 20\%). Kolejny zespół pochodził z badań sondażowo-weryfikacyjnych na grodzisku w Lipowcu (Lipowiec 1/2). Ten bardzo skromny materiał - zaledwie cztery ułamki naczyń całkowicie obtaczanych (GT V) - wydobyto z nawarstwień rumowiskowo-demolacyjnych konstrukcji wału. Na terenie osady znajdującej się bezpośrednio na zachód od grodziska (stanowisko nieznane $\mathrm{z}$ dokumentacji AZP) znaleziono pięć fragmentów naczyń tej samej grupy technicznej (Lipowiec 1/1). Niewielką wartością poznawczą charakteryzuje się też zespół ceramiczny z grodziska w Morlinach (Morliny 1/1). Pięć fragmentów naczyń całkowicie obtaczanych (GT V) znaleziono tam w trakcie badań sondażowych.

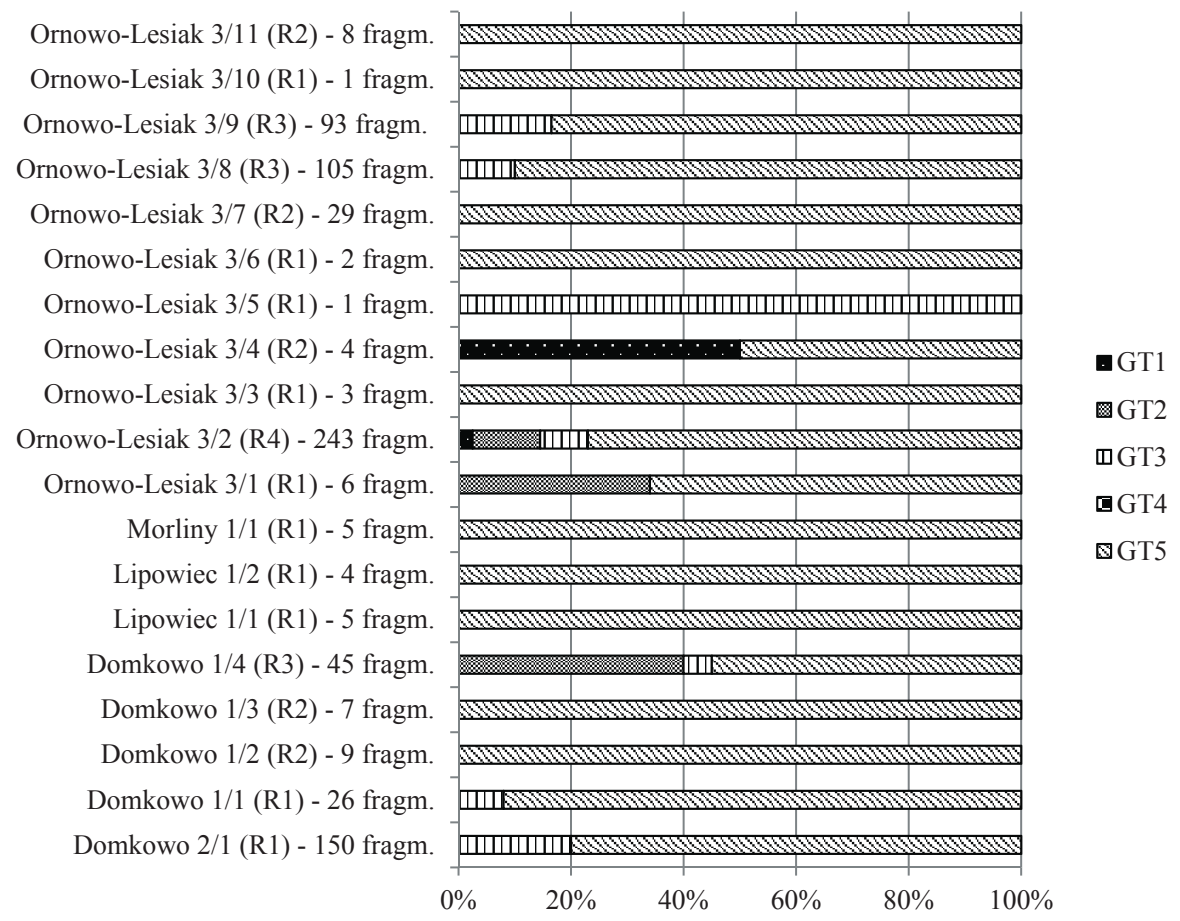

Ryc. 3. Mezoregion górnej Drwęcy. Udział poszczególnych grup technicznych w zespołach ceramicznych (oprac. S. Wadyl)

Fig. 3. Upper Drwęca Mesoregion. Percentage share of various categories of pottery assemblages (elab. by S. Wadyl) 


\section{Analiza materiatu ceramicznego ${ }^{3}$}

\section{1) Aspekt techniczno-technologiczny}

Fragmenty naczyń ręcznie lepionych (GT I - 3 fragmenty), znalezione tylko w dwóch zespołach ceramicznych (ryc. 3), charakteryzuje masa garncarska z domieszką niewielkiej ilości słabo obtoczonego i niewysortowanego materiału klastycznego w postaci średnio- i gruboziarnistego tłucznia mineralnego. Pod względem grubość ścianek ułamki reprezentują naczynia średnio grubościenne $(7 \mathrm{~mm}<\mathrm{Gmax} \leq 10 \mathrm{~mm})$.

Fragmenty naczyń ręcznie lepionych, przykrawędnie obtaczanych (GT II - 3\%, 22 fragmenty) stwierdzono w trzech zespołach, przy czym najwięcej w Domkowie (zespół Domkowo 1/4 - 40\%) oraz Ornowie-Lesiaku (zespół Ornowo-Lesiak 3/2-12\%). Zdecydowaną ich większości wykonano według receptury cechującej się obecnością w masie garncarskiej niewielkiej ilości źle wysortowanego i nieobtoczonego materiału klastycznego w postaci ziaren tłucznia mineralnego głównie o średnich i grubych frakcjach (96\%). W 60\% przypadków dodatkowo zastosowano domieszkę organiczną - słomianą sieczkę. Pojedyncze fragmenty (4\%) pochodzą z naczyń wykonanych z masy zawierającej większą ilość komponentów schudzających - zarówno dobrze obtoczonego, jak i ostrokrawędzistego materiału klastycznego o granulacji od 0,5 do $1,5 \mathrm{~mm}$. Powierzchnia zewnętrzna w większości przypadków jest lekko chropowata, na kilku fragmentach stwierdzono ślady po wygładzaniu za pomocą drewienka bądź kości. Jeden ułamek wylewu około $1,5 \mathrm{~cm}$ poniżej krawędzi ma otwór służący zapewne do podwieszenia naczynia. Żadnego dna nie udało się pewnie zaklasyfikować do tej grupy technicznej. Analiza grubości ścianek wykazała, że ułamki pochodzą z egzemplarzy średniościennych $(5 \mathrm{~mm} \leq \mathrm{Gmax} \leq 7 \mathrm{~mm})$ oraz średnio grubościennych, przy czym przeważają te ostatnie $(69,5 \%)$.

Fragmenty naczyń obtaczanych do największej wydętości brzuśca (GT III) stanowią drugą pod względem liczebności - po naczyniach całkowicie obtaczanych - grupę techniczną ( $9 \%$ - 67 fragmentów). Odnotowano je w siedmiu zespołach ceramicznych, przy czym cztery mają dużą wartość poznawczą. Największy udział ułamków naczyń tej grupy stwierdzono w Ornowie-Lesiaku (zespoły Ornowo-Lesiak 3/9 - 16,5\%), Ornowo-Lesiak

\footnotetext{
${ }^{3}$ Na potrzeby niniejszej pracy zmodyfikowano tzw. adalbertusowski schemat analizy opisowej naczyń ceramicznych (Chudziak, Poliński, Moszczyński 1997).
} 
3/8 - 10\%, Ornowo-Lesiak 3/2 - 8,5\%) oraz w Domkowie (zespół 1/4 - 8\%). Materiał ten cechuje w większości masa garncarska zawierająca niewielką ilość źle wysortowanego i nieobtoczonego ostrokrawędzistego tłucznia mineralnego średnio- i gruboziarnistego (87,5\%). Około 7\% stanowią ułamki naczyń wykonanych według receptury charakteryzującej się lepszym rozłożeniem komponentów oraz zawartością zarówno dobrze obtoczonego, jak i ostrokrawędzistego materiału klastycznego o frakcjach drobnoziarnistych i średnioziarnistych. W przypadku pozostałej część materiału ceramicznego należącego do tej grupy $(5,5 \%)$ odnotowano zastosowanie masy zawierającej w przewadze dobrze obtoczony materiał klastyczny. Na dwóch dnach stwierdzono ślady zastosowania podsypki mineralnej, jedno z nich jest płaskie, drugie zaś wklęsłe. W analizowanej grupie wyróżniono cztery klasy grubości ścianek naczyń: cienkie $(\mathrm{Gmax} \leq 5 \mathrm{~mm})$, średnie, średnio grube oraz grube (10 mm<Gmax). Połowa fragmentów (50\%) mieści się w klasie średnio grubościennej, nieco mniej (44\%) zaliczono do średniościennej zaś pojedyncze do ceramiki grubościennej i cienkościennej.

Do czwartej grupy technicznej (GT IV) zaliczono pojedyncze ułamki naczyń. Ze względu na niewielką liczebność tej kategorii zrezygnowano z analizy technologicznej.

W opisywanych zespołach największy udział mają fragmenty naczyń całkowicie obtaczanych (GT V - 81,5\%, 608 fragmentów). Odnotowano je niemal we wszystkich zespołach, przy czym w tych o dużej wartości poznawczej ich udział wahała się od 55\% (Domkowo 1/4) do 90\% (Ornowo-Lesiak 3/8). W większości zespołów o mniejszej wartości poznawczej materiał ceramiczny tej grupy technicznej jest jedynym komponentem. Dla opisywanej grupy naczyń charakterystyczne jest stosowanie receptury masy garncarskiej zawierającej niewielką ilość drobnoziarnistego piasku i wtręty średnioziarnistego, ostrokrawędzistego tłucznia mineralnego (48,6\%), w pojedynczych przypadkach zaś domieszkę tłucznia ceramicznego oraz domieszkę organiczną - słomianą sieczkę. Niewiele mniejszy udział stanowią fragmenty naczyń wykonanych z masy zawierającej niewielką ilość słabo obtoczonego bądź nieobtoczonego materiału klastycznego - ostrokrawędzistego tłucznia mineralnego (37,6\%). Najrzadziej stosowana receptura masy garncarskiej $(13,8 \%)$ cechuje się przewagą dość dobrze obtoczonego materiału klastycznego. Powierzchnie zewnętrzne naczyń w większości przypadków zostały wykończone dość starannie, choć w znacznym stopniu rozpoznanie śladów ich wykończenia utrudniało zdobienie. W 13 przypadkach możliwe było określenie cech technologicznych den - przeważają wklęsłe (dziewięć egzemplarzy), 
pozostałe są płaskie.. W dziewięciu przypadkach określono rodzaj zastosowanej podsypki - zdecydowanie częściej ( 8 egz.) jest to tłuczeń kamienny, tylko w jednym podsypka organiczna. Naczynia z tej grupy technicznej zaliczono do czterech klas grubości: cienkościenne, średniościenne, średnio grubościenne oraz grubościenne. Największy udział stanowiły egzemplarze średniościenne (64\%), zdecydowanie mniej było średnio grubościennych (27\%), sporadycznie zaś odnotowano cienkościenne i grubościenne.

\section{2) Aspekt morfologiczny}

W analizowanym zbiorze znalazły się 153 części naczyń zachowanych co najmniej do największej wydętości brzuśca. Zrekonstruowano 16 egzemplarzy przyporządkowanych do trzech rodzajów form, które wydzielono biorąc pod uwagę ukształtowanie brzuśca - baniastych (B), esowatych (E) i dwustożkowatych (D). Przeważają wyroby całkowicie obtaczane (GT V - 75\%, 12 egz.), przykrawędnie obtaczane (GT II) oraz obtaczane do największej wydętości brzuśca (GT III) stanowiły po 12,5\% (po 2 egz.).

Wśród naczyń ręcznie lepionych, przykrawędnie obtaczanych znalazł się jeden okaz reprezentujący rodzinę form baniastych (B) i jeden form esowatych (E) (ryc. 4). Naczynie baniaste $\left(\mathrm{B}_{1}\right)$ ma brzusiec znacznie wydęty, ze średnio wysoko umieszczoną największą wydętością oraz wylew nieznacznie wychylony na zewnątrz, lekko pogrubiony przy krawędzi. Egzemplarz esowaty $\left(E_{1}\right)$ jest słabo profilowany, ma słabo wydęty brzusiec oraz długi, silnie wychylony na zewnątrz wylew.

W grupie wyrobów ręcznie lepionych, obtaczanych do największej wydętości brzuśca zrekonstruowano formę baniastą (B ) i dwustożkowatą (D) (ryc. 5). Naczynia baniaste ( $\mathrm{B}_{1}$ ) mają słabo wydęty brzusiec $\mathrm{z}$ wysoko umieszczoną największą wydętością oraz krótki, silnie odgięty na zewnątrz wylew. Forma dwustożkowata $\left(\mathrm{D}_{1}\right)$ charakteryzuje się średnio wysoko umieszczonym załomem brzuśca i krótkim, nieznacznie odgiętym wylewem.

Wśród naczyń całkowicie obtaczanych wyróżniono formy baniaste (B - 40\%, 5 egz.) oraz esowate (E), przy czym ostatnie stanowią ponad $60 \%$ (7 egz.) (ryc. 6). Egzemplarze baniaste należą do dwóch typów. Jeden ma silnie wydęty brzusiec ze średnio wysoko umieszczoną największą wydętością oraz silnie wychylony na zewnątrz wylew $\left(\mathrm{B}_{1}\right)$. Drugi charakteryzuje się silnie wydętym brzuścem, z wysoko umieszczoną największą wydętością oraz stosunkowo długim i silnie wychylonym na zewnątrz wylewem $\left(\mathrm{B}_{2}\right)$. Wśród form esowatych wyróżniono pięć typów. Jeden z nich stanowią naczynia słabo 

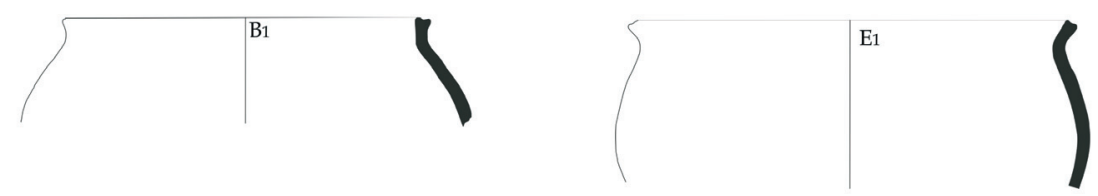

Ryc. 4. Mezoregion górnej Drwęcy. Typy naczyń przykrawędnie obtaczanych (GT II) (rys. S. Wadyl)

Fig. 4. Upper Drwęca Mesoregion. Partially wheel-thrown vessel types (GT II) (drawn by S. Wadyl)
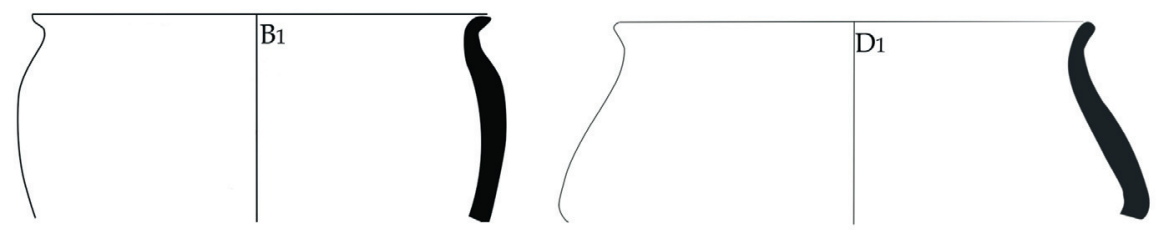

Ryc. 5. Mezoregion górnej Drwęcy. Typy naczyń obtaczanych do największej wydętości brzuśca (GT III) (rys. S. Wadyl)

Fig. 5. Upper Drwęca Mesoregion. Partially wheel-thrown vessel types (GT III) (drawn by S. Wadyl)

profilowane z silnie wydętym brzuścem oraz słabo wychylonym wylewem $\left(E_{1}\right)$. W drugim typie znalazły się dwie odmiany: formy silnie profilowane z dość wydętym, silnie zwężającym się w kierunku dna brzuścem i wyraźnie wychylonym na zewnątrz, pogrubionym wylewem $\left(\mathrm{E}_{2 \mathrm{a}}\right)$ oraz słabiej profilowane, $\mathrm{z}$ mniej wychylonym wylewem $\left(\mathrm{E}_{2 \mathrm{~b}}\right)$. Do trzeciego typu zaliczono naczynie ze słabo wydętym brzuścem i lekko wychylonym na zewnątrz, pogrubionym wylewem $\left(\mathrm{E}_{3}\right)$. Kolejne dwa typy to formy silnie profilowane, z wyodrębnioną szyjką, silnie wydętym brzuścem o wysoko umieszczonej największej wydętości $\left(\mathrm{E}_{4}\right)$ oraz szerokootworowe, ze słabo wydętym brzuścem o wysoko umieszczonej największej wydętości $\left(\mathrm{E}_{5}\right)$.

\section{3 ) Aspekt stylistyczny}

Ponad połowę analizowanego materiału ceramicznego stanowią fragmenty zdobione (448 szt.; 60\%). W pierwszym etapie, w obrębie poszczególnych grup technicznych (GT I, GT II-III, GT V), wyróżniono wątki zdobnicze, w kolejnym - systemy ornamentacyjne na całych naczyniach bądź fragmentach zachowanych co najmniej do największej wydętości brzuśca. 

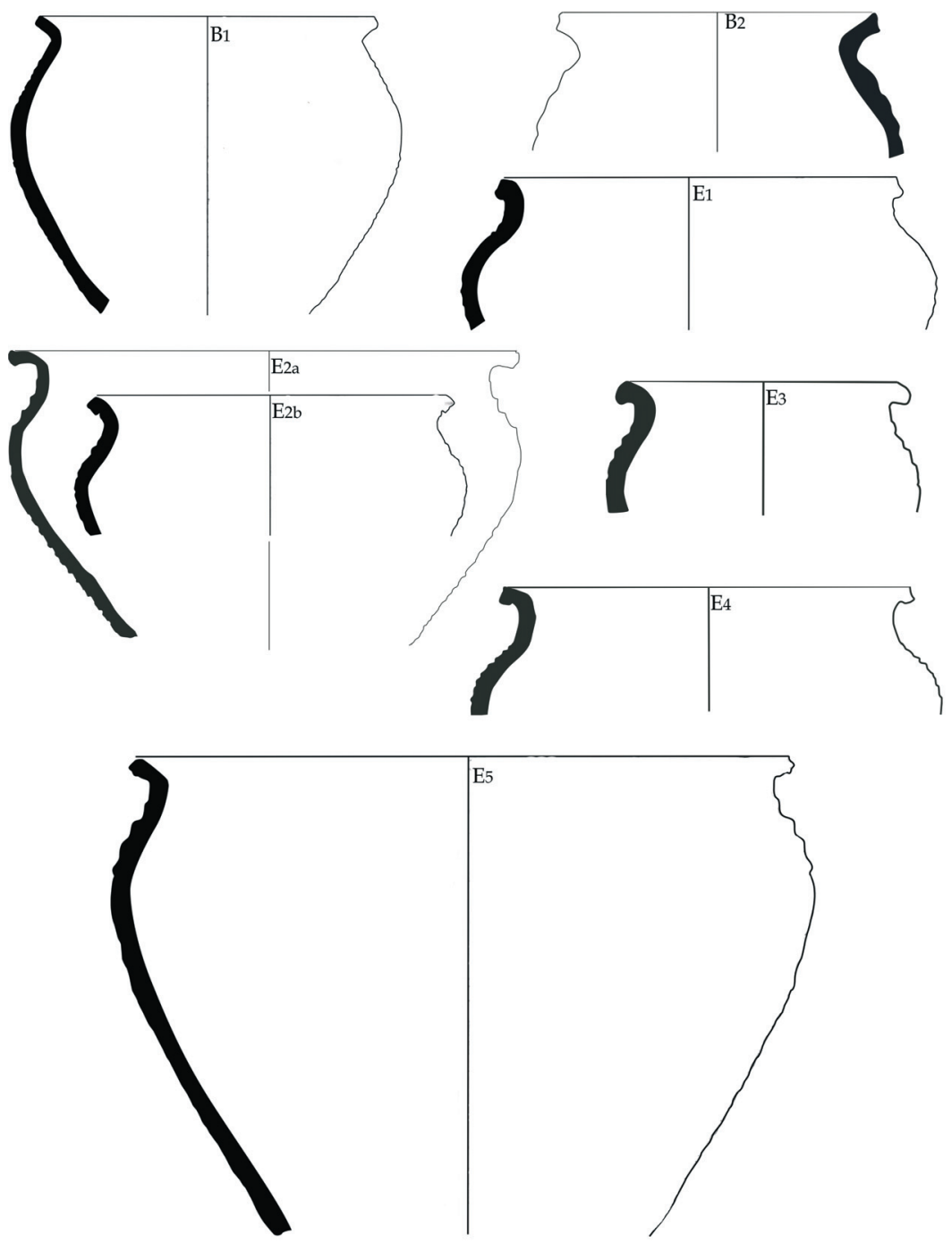

Ryc. 6. Mezoregion górnej Drwęcy. Typy i odmiany naczyń całkowicie obtaczanych (GT V) (rys. S. Wadyl)

Fig. 6. Upper Drwęca Mesoregion. Fully wheel-thrown vessel types and variants (GT V) (drawn by S. Wadyl)

Wykończenie powierzchni, które można traktować jako element dekoracji stwierdzono na obu egzemplarzach ręcznie lepionych (GT I). Mają one karbowane wylewy (WZ.IX.e; ryc. 7), co jest charakterystyczne dla zachodniobałtyjskiej tradycji garncarskiej (Wróblewski, Nowakiewicz 2003, s. 174-175). 


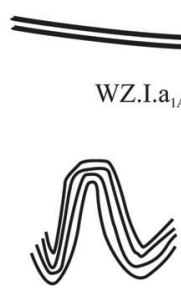

WZ.I. $a_{3}$

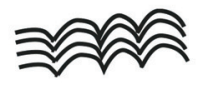

WZ.I. $\mathrm{a}_{2 \mathrm{~B}}$

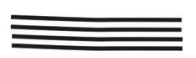

WZ.I. $a_{1 \mathrm{c}}$

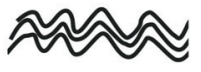

WZ.I.a 2A2 $_{2}$

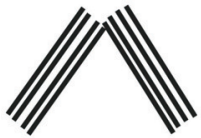

WZ.I.b ${ }_{3 \mathrm{~B}}$
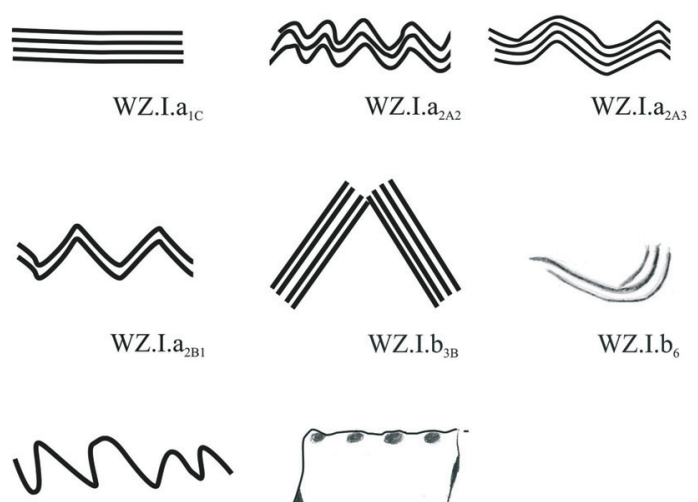

WZ.III. $a_{3}$

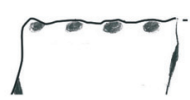

WZ.IX. e

WZ.III. $a_{1}$

WZ.III. $a_{2}$

Ryc. 7. Mezoregion górnej Drwęcy. Wątki zdobnicze występujące na naczyniach ręcznie lepionych (GT I) oraz częściowo obtaczanych (GT II-III) (rys. S. Wadyl)

Fig. 7. Upper Drwęca Mesoregion. Decoration motifs distinguished on the handmade (GT I) and partially wheel-thrown vessels (GT II-III) (drawn by S. Wadyl)

W przypadku naczyń częściowo obtaczanych (GT II-III) ornament odnotowano na 37 ułamkach (około 50 \%). Łącznie wyróżniono 13 wątków zdobniczych należących do dwóch grup - wykonane wielozębnym narzędziem grzebykowatym (WZ.I. i WZ.III). Zdecydowanie przeważają zdobienia należące do pierwszej grupy (WZ.I. - 86\%; ryc. 8): przede wszystkim pasma w układzie horyzontalnym (WZ.I.a ${ }_{1 \mathrm{~A}-\mathrm{C}}$ ), a także pasma falistych linii o łagodnym bądź załamującym się profilu (WZ.I.a $\left.{ }_{2 \mathrm{~A} 1-3}\right)$, rzadziej pasma faliste o wysokiej amplitudzie (WZ.I.a.), sporadycznie zaś krótkie, ukośne pasma układające się w ramiona trójkąta równoramiennego (WZ.I.b ${ }_{3 \mathrm{~B}}$ ) oraz krótkie, łukowate pasma (WZ.I.b $)$. W drugiej grupie wątków odnotowano pojedyncze linie horyzontalne (WZ.III.a $)$ bądź faliste (WZ.III.a ${ }_{2-3}$ ).

Pełny układ zdobniczy zarejestrowano zaledwie na pięciu naczyniach. Wyróżniono cztery systemy ornamentacyjne z grupy systemów jednowątkowych (SO.I.) i dwuwątkowych (SO.II.) (ryc. 9). Wśród układów jednowątkowych wyróżniono jedynie kompozycje utworzone z pasm linii falistych: powtarzających się, o załamującym się przebiegu, naniesione w górnej części brzuśca (SO.I.a) oraz potrójnych o załamującym się, zbliżonym do symbolu zygzaka.

Wśród dwóch systemów dwuwątkowych wyróżniono jeden w układzie hierarchicznym, utworzony z powtarzających się pasm podwójnej linii fali- 


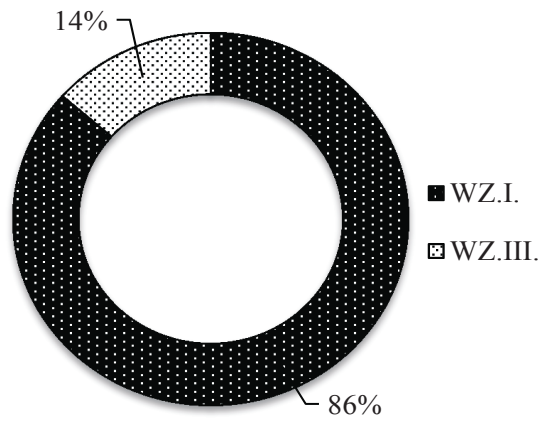

Ryc. 8. Mezoregion górnej Drwęcy. Udział procentowy wątków zdobniczych w grupie naczyń częściowo obtaczanych (GT II-III) (oprac. S. Wadyl)

Fig. 8. Upper Drwęca Mesoregion. Percentage share of decoration motifs noted on partially wheel-thrown vessels (GT II-III) (elab. by S. Wadyl)
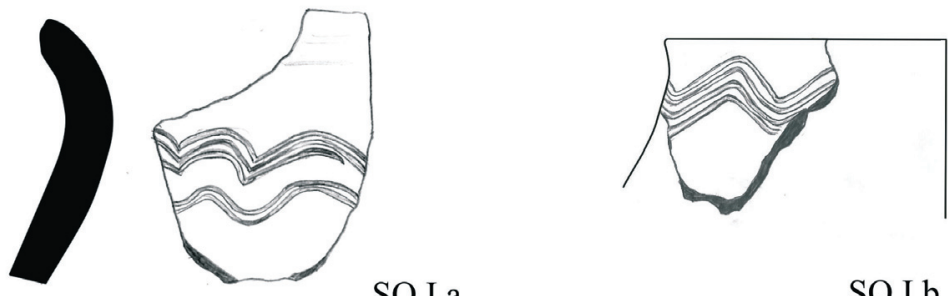

SO.I.a

SO.I.b
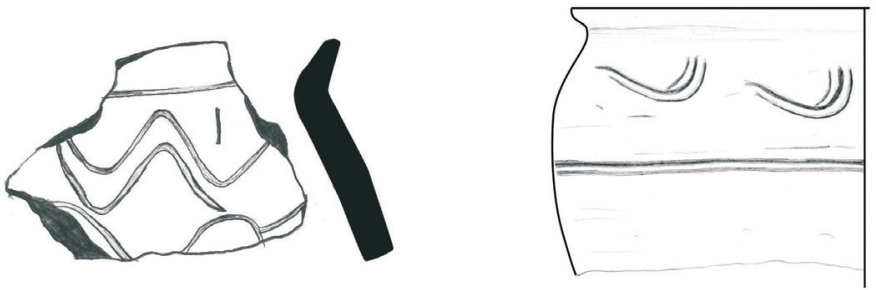

SO.II.a

SO.II.b

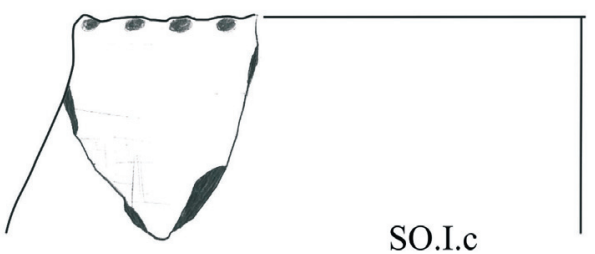

Ryc. 9. Mezoregion górnej Drwęcy. Systemy ornamentacyjne występujące na naczyniach ręcznie lepionych (GT I) i częściowo obtaczanych (GT II-III) (rys. S. Wadyl)

Fig. 9. Upper Drwęca Mesoregion. Decorative compositions distinguished on the handmade (GT I) and partially wheel-thrown vessels (GT II-III) (drawn by S. Wadyl) 
stej o łagodnym przebiegu, zwieńczonych wątkiem uzupełniającym w postaci pojedynczej linii poziomej (SO.II.a). Drugi składa się z wątków równoważnych: pasmo podwójnej linii falistej znajduje się na największej wydętości brzuśca, w jego górnej części zaś krótkie pasma o łukowatym przebiegu (SO. II.b).

W grupie naczyń całkowicie obtaczanych (GT V) materiał zdobiony stanowi 84,3\%, przy czym odnotowano tu znacznie większe zróżnicowanie wątków niż na wyrobach częściowo obtaczanych - łącznie $18 \mathrm{w}$ siedmiu grupach (ryc. 10, 11). Najliczniej występują wątki zaliczone do trzeciej grupy (WZ. III - 61\% całego materiału zdobionego tej grupy technicznej), głównie w postaci dookolnych żłobków (WZ.III.a), często samodzielnie albo w większości kompozycji dwu- i wielowątkowych jako wątek główny. Stosunkowo liczne są pojedyncze, faliste linie (WZ.III.a ${ }_{2-3}$ ). Stwierdzono też znaczny udział tzw. żeberek (WZ.VIII): o profilu łagodnym, falistym (WZ.VIII.a) oraz załamującym się (WZ.VIII.b).

Znacznie mniejszy odsetek (rzędu 11\% całego materiału zdobionego tej grupy technicznej) stanowią odciski wykonane wielozębnym narzędziem grzebykowatym (WZ.II); odnotowano tu ukośne pasma (WZ.II.c), a także odciski grzebyka stykające się, w kształcie pochylonej na prawo litery L (WZ.II.e) oraz odciski tworzące znak krzyża (X; WZ.II.f). Charakterystycznym, licznie występującym zdobieniem są odciski stempla wielodzielnego (WZ.V - 8\%) w kształcie rombu (WZ.V.c, WZ.V.j), prostokąta (WZ.V.i), owalu (WZ.V.h) oraz odciski przypominające pochyloną w prawo literę L (WZ.V.k). Wątki z pozostałych grup - wykonane wielozębnym narzędziem grzebykowatym (WZ.I i WZ.IV) występują sporadycznie, ich udział nie przekracza $2 \%$.

W grupie naczyń całkowicie obtaczanych wyróżniono cztery grupy systemów ornamentacyjnych (SO.I., SO.II., SO.III., SO.IV.) (ryc. 12). Na 19 pojemnikach zachowały się w stanie pozwalającym na odczytanie pełnego układu zdobniczego; łącznie wyróżniono osiem systemów (ryc. 13). Na naczyniach zdobionych układem jednowątkowym (48\%) stwierdzono wyłącznie dookolne żłobki w układzie horyzontalnym (WZ.III.a $)$ pokrywającym większą część naczynia (SO.I.a). Systemy dwuwątkowe występują również dość często (33\%), przy czym w tej grupie zaobserwowano znaczne zróżnicowanie kompozycji (pięć rodzajów). Wszystkie mają charakter hierarchiczny z wątkiem głównym w postaci dookolnych żłobków i wątkiem uzupełniającym utworzonym przez pasma falistych linii (SO.II.a), odciski stempla (SO.II.b) oraz odciski narzędzia grzebykowatego (SO.II.c-e), umieszczone 


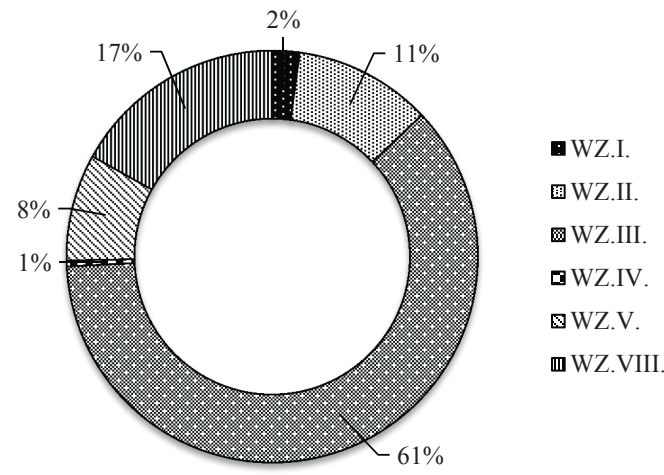

Ryc. 10. Mezoregion górnej Drwęcy. Udział procentowy wątków zdobniczych w grupie naczyń całkowicie obtaczanych (GT V) (oprac. S. Wadyl)

Fig. 10. Upper Drwęca Mesoregion. Percentage share of decoration motifs noted on the fully wheel-thrown vessels (GT V) (elab. by S. Wadyl)

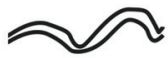

WZ.I. $\mathrm{a}_{2 \mathrm{AI}}$

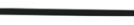

WZ.III. $a_{1}$

ํㅐㅂำ

WZ.V.h

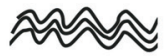

WZ.I. $a_{2 \mathrm{~A} 2}$

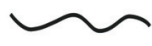

WZ.III. $\mathrm{a}_{2}$

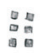

WZ.V.i

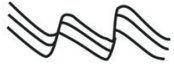

WZ.I. $a_{2 D}$

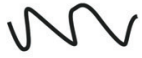

WZ.III.a

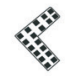

WZ.V.k

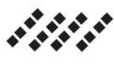

WZ.II.c
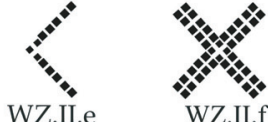

WZ.II.f

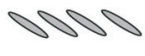

WZ.IV.a

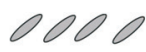

WZ.IV.b

WZ.V.C

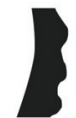

WZ.VIII.a

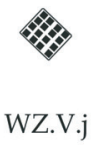

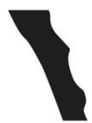

WZ.VIII.b

Ryc. 11. Mezoregion górnej Drwęcy. Wyróżnione wątki zdobnicze występujące na naczyniach całkowicie obtaczanych (GT V) (rys. S. Wadyl)

Fig. 11. Upper Drwęca Mesoregion. Decoration motifs distinguished on the fully wheel-thrown vessels (GT V) (drawn by S. Wadyl)

w wydzielonej strefie w górnej części brzuśca bądź w strefie największej jego wydętości. Na jednym naczyniu odnotowano system trójwątkowy (SO. III.a): w górnej części brzuśca ornament w postaci tzw. żeberek, w strefie największej jego wydętości dwa pasma odcisków grzebyka tworzących formę krzyża bądź litery X. Całość kompozycji dopełniają dookolne żłobki pokrywające dolną część pojemnika. Również w jednym przypadku stwierdzono kompozycję wielowątkową (SO.IV.a): w górnej części brzuśca tzw. żeberko, w strefie jego największej wydętości pasma odcisków stempla wielodzielnego 


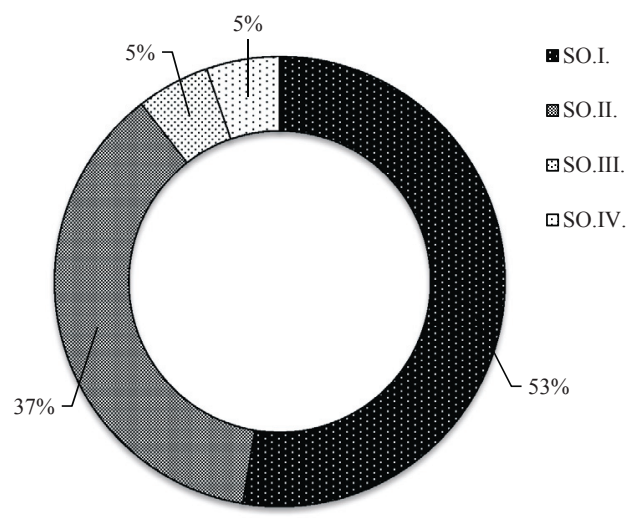

Ryc. 12. Mezoregion górnej Drwęcy. Udział procentowy grup systemów ornamentacyjnych wśród naczyń całkowicie obtaczanych (GT V) (oprac. S. Wadyl)

Fig. 12. Upper Drwęca Mesoregion. Percentage share of decorative compositions noted on fully wheel-thrown vessels (GT V) (elab. by S. Wadyl)

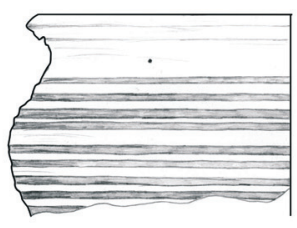

SO.I.a

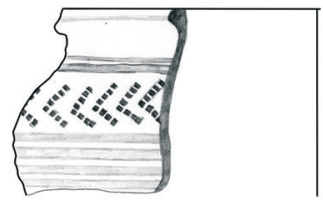

SO.II.c

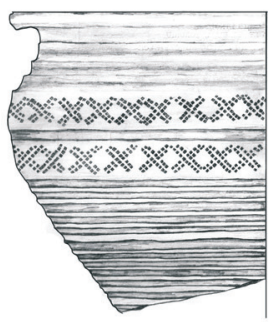

SO.III.a

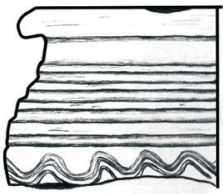

SO.II.a

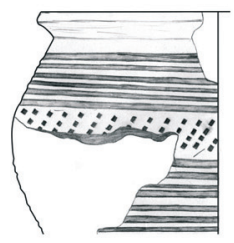

SO.II.d

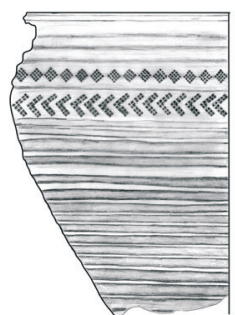

SO.IV.a

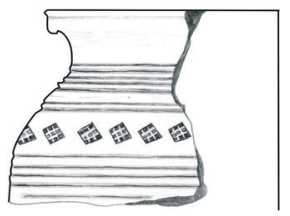

SO.II.b

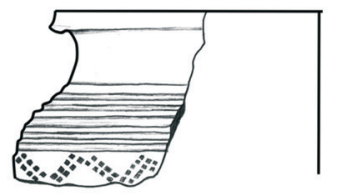

SO.II.e

Ryc. 13. Mezoregion górnej Drwęcy. Systemy ornamentacyjne występujące na naczyniach całkowicie obtaczanych (GT V) (rys. S. Wadyl)

Fig. 13. Upper Drwęca Mesoregion. Decorative compositions distinguished on fully wheel-thrown vessels (GT V) (drawn by S. Wadyl) 
w kształcie przechylonej litery L, powyżej pasmo z odciskami stempla w formie rombu składającego się z 16 kwater. Na dolnej część czaszy widnieją szerokie pasma dookolnych żłobków, sięgające do strefy przydennej.

\section{Zwiazki chronologiczno-przestrzenne ceramiki z mezoregionu górnej Drwęcy}

Odzwierciedleniem najstarszych tradycji garncarstwa wczesnośredniowiecznego na obszarze dorzecza górnej Drwęcy są niezbyt liczne, lepione bez zastosowania koła garncarskiego naczynia. Pojedyncze okazy z tej grupy stwierdzono w kilku zespołach z Ornowa-Lesiaka; mają one esowato-jajowate brzuśce i wylewy wykończone odciskami palcowymi (ryc. 14: e, h). Motyw ten jest charakterystyczny dla zachodniobałtyjskiej (postolsztyńskiej) tradycji garncarskiej. Podobne wykończenie brzegów naczyń całkowicie ręcznie lepionych spotykane jest jednak w zespołach z różnych części Słowiańszczyzny ${ }^{4}$.

Niezbyt licznie są też reprezentowane egzemplarze ręcznie lepione, przykrawędnie obtaczane, mieszczące się w bardziej progresywnym nurcie wczesnośredniowiecznego garncarstwa (udział rzędu 5\%). Ich cechą charakterystyczną jest brak zdobień. Początki nowej techniki lepienia naczyń, związanej z wykorzystaniem rotacji kręgu garncarskiego odnosi się do VII wieku (Parczewski 1988, s. 35; Szymański 2000, s. 368). W zespołach ceramicznych z dorzecza górnej Drwęcy, zawierających egzemplarze przykrawędnie obtaczane, znajdują się też wyroby obtaczane do największej wydętości brzuśca oraz całkowicie obtaczane (zespoły Ornowo-Lesiak 3/1-2, Domkowo 1/4). Wśród naczyń przykrawędnie obtaczanych znalazły się formy baniaste i esowate. Okazy baniaste o silnie wydętym brzuścu i nieznacznie wychylonym na zewnątrz wylewie (ryc. 14: d; ryc. 15: d) mają odpowiedniki na obszarze strefy chełmińsko-dobrzyńskiej (Chudziak 1991, s. 65, 27, ryc. 6; Weinkauf 2011). Odmienny morfologicznie typ reprezentują naczynia esowate ze śred-

\footnotetext{
${ }^{4}$ Znaleziska takich naczyń pochodzą między innymi z Kałdusa na ziemi chełmińskiej, Drohiczyna czy też Krakowa-Nowej Huty. Również w kręgu kultury praskiej i kijowskiej znane są stanowiska, gdzie znaleziono analogicznie zdobione wyroby (Weinkauf 2011 - tam dalsza literatura). Znaczne nagromadzenie ręcznie lepionych naczyń z odciskami palcowymi na krawędziach wylewów występuje także nad dolnym Dunajem, szczególnie na wschód od Karpat. Najwcześniejsze egzemplarze z tak zdobionymi (karbowanymi) wylewami zostały znalezione w kontekstach pewnie datowanych na 2. połowę VI wieku, natomiast bardziej rozpowszechnione są one w materiałach z przełomu VI i VII wieku. Występują również na stanowiskach awarskich, na przykład w Dunaujvaros, w zespołach grobowych w Crimea (Curta 2006, s. 290-294).
} 

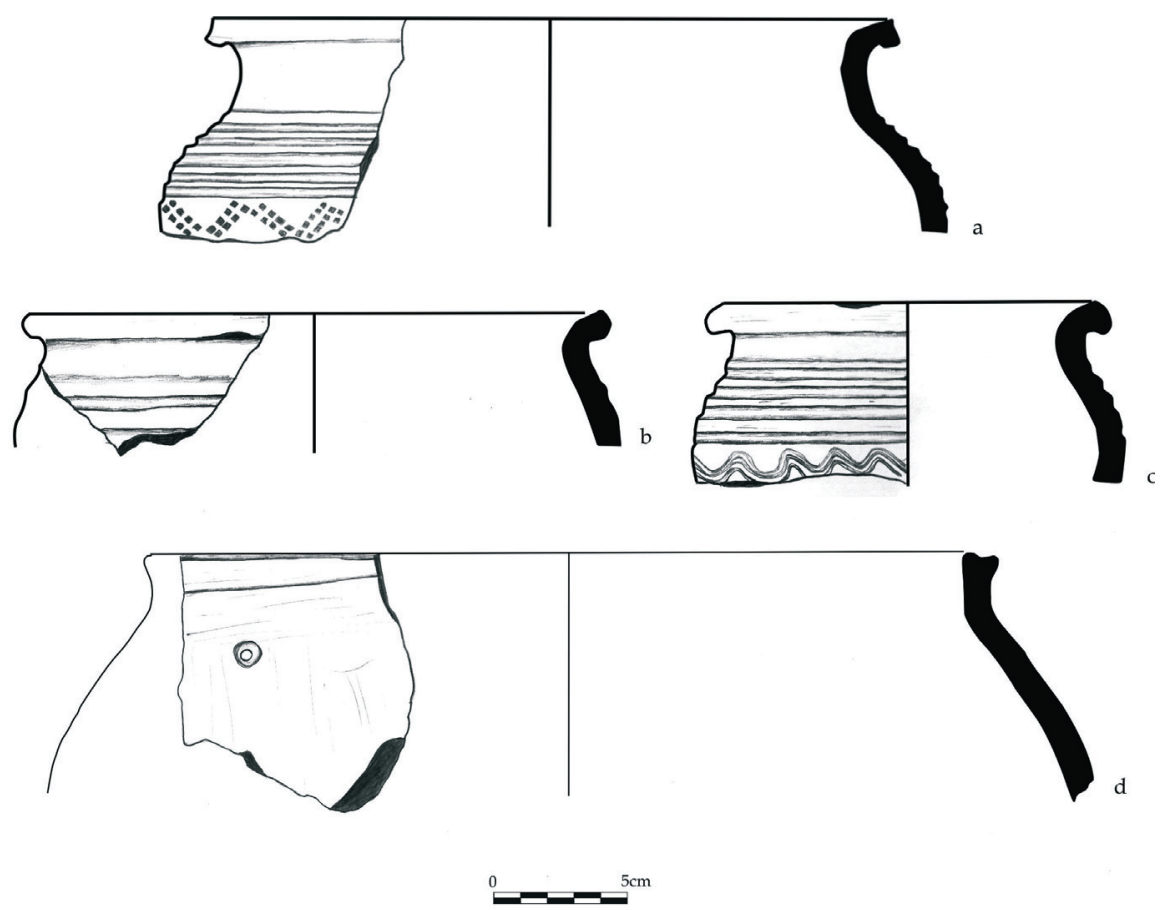

Ryc. 14. Domkowo, gm. Grunwald, stanowisko 1. Naczynia ceramiczne z warstwy 4 (bruk kamienny): a-c-GT V; d-GT II (rys. S. Wadyl)

Fig. 14. Domkowo, comm. Grunwald, site 1. Pottery from the layer 4 (stone pavement): a-c-GT V; d-GT II (drawn by S. Wadyl)

nio wydętym brzuścem o średnio wysoko umieszczonej największej wydętości oraz z silnie wychylonym na zewnątrz wylewem. Należą one do najbardziej powszechnych typów wyrobów przykrawędnie obtaczanych i mają swoje odpowiedniki w materiałach typu Sukow/rodzina typów B (Łosiński, Rogosz 1983, s. 203, ryc. 176). Naczynia tego typu datowane są od VII do IX wieku (Dulinicz 2001, s. 47-49).

W analizowanym zbiorze dość liczne są wyroby obtaczane do największej wydętości brzuśca, pod względem technologicznym nieodbiegające od opisanych wyżej; ich udział stwierdzono w siedmiu zespołach, zazwyczaj nie przekracza on $20 \%$. W tej grupie wyróżniono naczynia baniaste i dwustożkowate. Okazy baniaste mają słabo wydęty brzusiec z wysoko umieszczoną największą wydętością (ryc. 5; ryc. 16: g), dwustożkowate zaś średnio wysoko umieszczony załom brzuśca i krótki, nieznacznie odgięty na zewnątrz wylew (ryc. 5; ryc. 16: c). Naczynia są zdobione wielozębnym narzędziem grzebykowatym $-\mathrm{z}$ reguły pasmami w układzie horyzontalnym, a także pasmami 

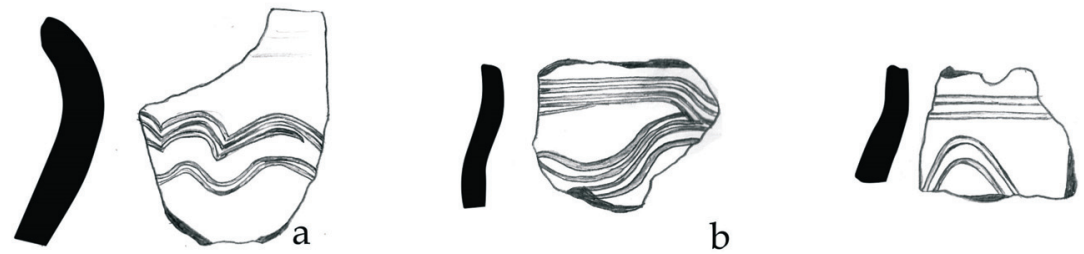

b

C
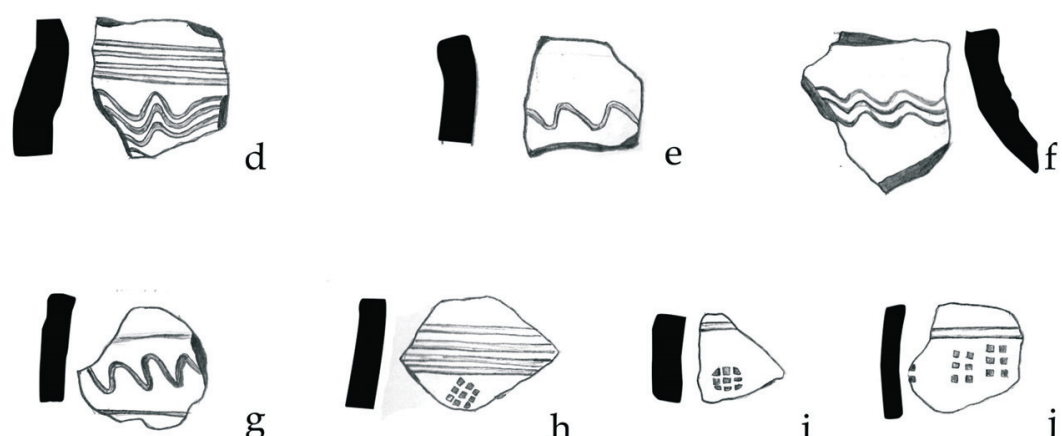

g
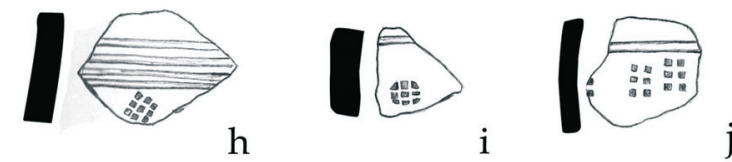

0

$5 \mathrm{~cm}$

Ryc. 15. Domkowo, gm. Grunwald, stan. 2. Fragmenty naczyń ceramicznych z powierzchni osady (rys. S. Wadyl)

Fig. 15. Domkowo, comm. Grunwald, site 2. Pottery collected during the surface survey (drawn by S. Wadyl)

falistych linii o łagodnym bądź załamującym się profilu, rzadziej falistymi pasmami o wysokiej amplitudzie, sporadycznie zaś krótkimi maźniętymi liniami. Ornamentyka ta ma szeroki zasięg występowania, mieszczący się w nurcie feldbersko-menkendorfskim. Materiały z dorzecza górnej Drwęcy nawiązują do interregionalnego nurtu wytwórczości garncarskiej nazywanego ceramiką typu D/Menkendorf (Schuldt 1956, s. 9-16; Łosiński, Rogosz 1983, s. 205-208, ryc. 178). Zwarte terytorium występowania tego nurtu wytwórczości ceramicznej rozciąga się od wschodniego Holsztynu po Pomorze Gdańskie i strefę chełmińsko-dobrzyńską (Łosiński 1996, s. 435-439). Chronologia przyjęta dla naczyń typu Menkendorf obejmuje okres od końca VIII do XI wieku, przy czym największe ich natężenie występuje w materiałach z X stulecia (Dulinicz 2001, s. 53-54). Wyroby obtaczane poniżej największej wydętości brzuśca stanowią znikomą część analizowanego zbioru. Nie stwierdzono wśród nich fragmentów charakterystycznych. 

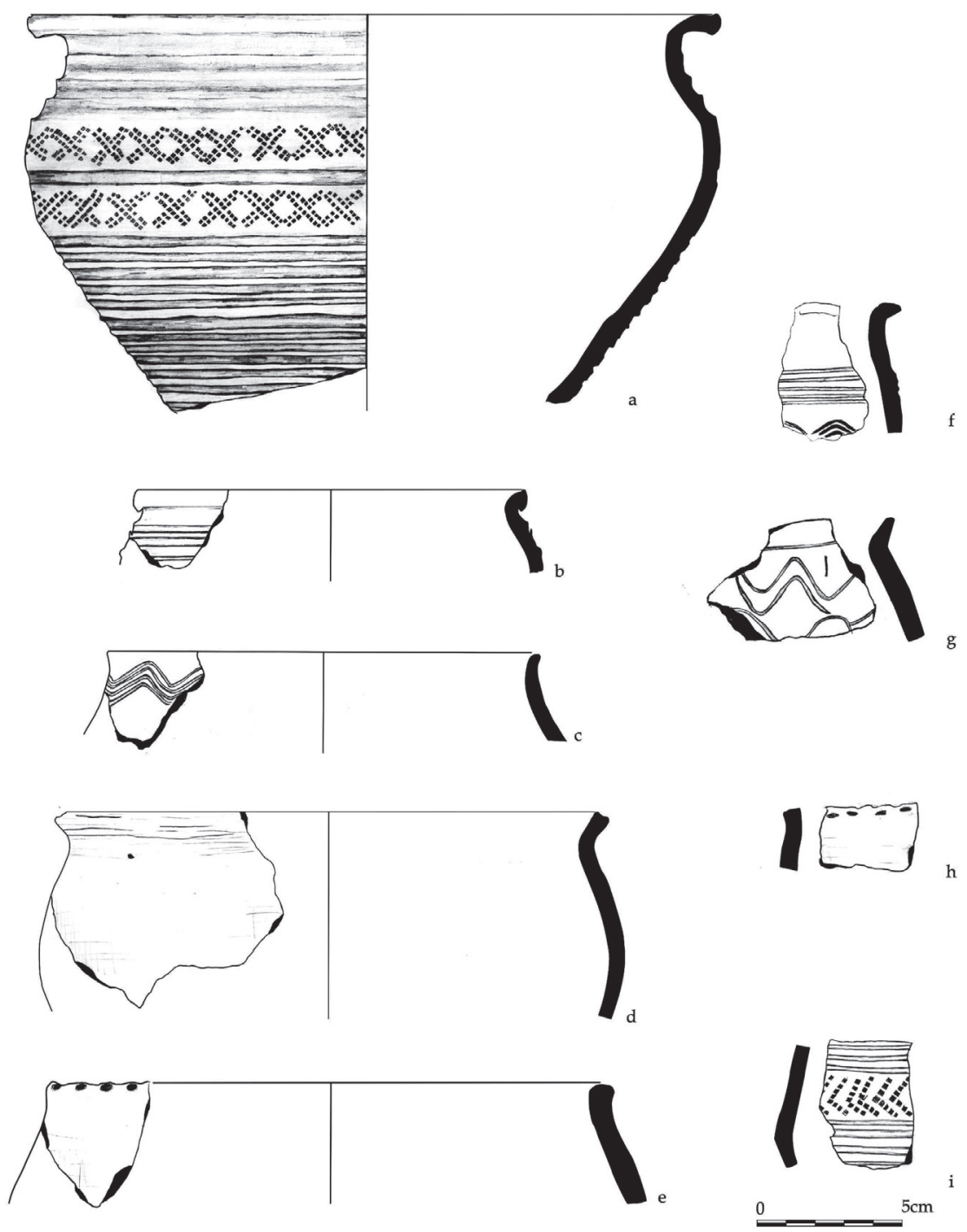

Ryc. 16. Ornowo-Lesiak, gm. Ostróda, stanowisko 3, wykop 1/2011. Naczynia ceramiczne z ziemianki (obiekt 1; a-d, f-i) oraz z warstwy 7 (e): a, b, f-i-GT V; c, g-GT III; d-e, h- GT I (rys. S. Wadyl)

Fig. 16. Ornowo-Lesiak, comm. Ostróda, site 3 , trench $1 / 2011$. Pottery from pithouse (obiect 1, a-d, f-i), and layer 7 (e): , b, f-i - GT V; c, g-GT III; d-e, h - GT I (drawn by S. Wadyl) 
Naczynia całkowicie obtaczane charakteryzują się dość urozmaiconym asortymentem form oraz stosunkowo zwartym zestawem ornamentów. Wśród 15 określonych typologicznie okazów siedem należy do esowatych, cztery do baniastych, jeden do dwustożkowatych. Formy esowate z reguły mają silnie wydęty brzusiec, ze średnio wysoko umieszczoną największą wydętością. Były jednymi z najbardziej rozpowszechnionych na terenach Słowiańszczyzny Zachodniej w młodszych fazach wczesnego średniowiecza. W materiałach ceramicznych ze Szczecina określane są jako rodzina typów G, zaś z Meklemburgii - typem Vipperow (Schuldt 1956; Łosiński, Rogosz 1983, s. 212-213; Stanisławski 2012, s. 63). Część naczyń esowatych cechuje bogata ornamentyka strefowa (ryc. 14: a; ryc. 16: a). Szczególnie często występują kompozycje składające się z wątku w postaci dookolnych żłobków umieszczanych $\mathrm{w}$ dolnej części brzuśca, uzupełnianego żeberkami znajdującymi się w górnej części czaszy oraz odciskami stempla tuż powyżej największej wydętości brzuśca. Mniej liczne są okazy z wyodrębnioną szyjką i wyraźnie wydętym brzuścem z wysoko umieszczoną największą wydętością (ryc. 15: a), nawiązujące do form typu J/Teterow (Łosiński, Rogosz 1983, s. 215, ryc. 189; Stanisławski 2012, s. 66-67 - tam dalsza literatura). Zdecydowana większość naczyń określanych jako J/Teterow ma baniasty brzusiec, niemniej jednak wyodrębniona szyjka oraz krótki, nieznaczne wychylny na zewnątrz wylew przemawiają za taką klasyfikacją tych okazów. Formy baniaste charakteryzują się silnie wydętym brzuścem, ze średnio wysoko umieszczoną największą wydętością oraz silnie wychylonym na zewnątrz wylewem (ryc. 16: d, f). Zdobione są systemem dwuwątkowym utworzonym $\mathrm{z}$ wątku głównego w postaci dookolnych żłobków, uzupełnionego umieszczonymi w wydzielonej strefie, w górnej części brzuśca, falistymi pasmami bądź ukośnymi odciskami grzebyka. Również i te naczynia nawiązują do form określanych jako $\mathrm{G}_{1}$ Vipperow (Łosiński, Rogosz 1983, s. 213, 215, ryc. 186). Warto zwrócić uwagę na brak naczyń z cylindryczną szyjką oraz tzw. pucharków na pustej nóżce.

Na wyrobach całkowicie obtaczanych odnotowano znacznie większe niż w przypadku innych grup technologicznych zróżnicowanie wątków zdobniczych. W większości kompozycji dwu- i wielowątkowych bruzdy-żłobki stanowią wątek główny. Stosunkowo często występują również zdobienia w postaci pojedynczej linii falistej oraz tzw. żeberka. Te ostanie oraz odciski stempla wielodzielnego, a także odciski wykonane wielozębnym narzędziem grzebykowatym należą do najbardziej charakterystycznych motywów zdobniczych w tej kategorii naczyń. 

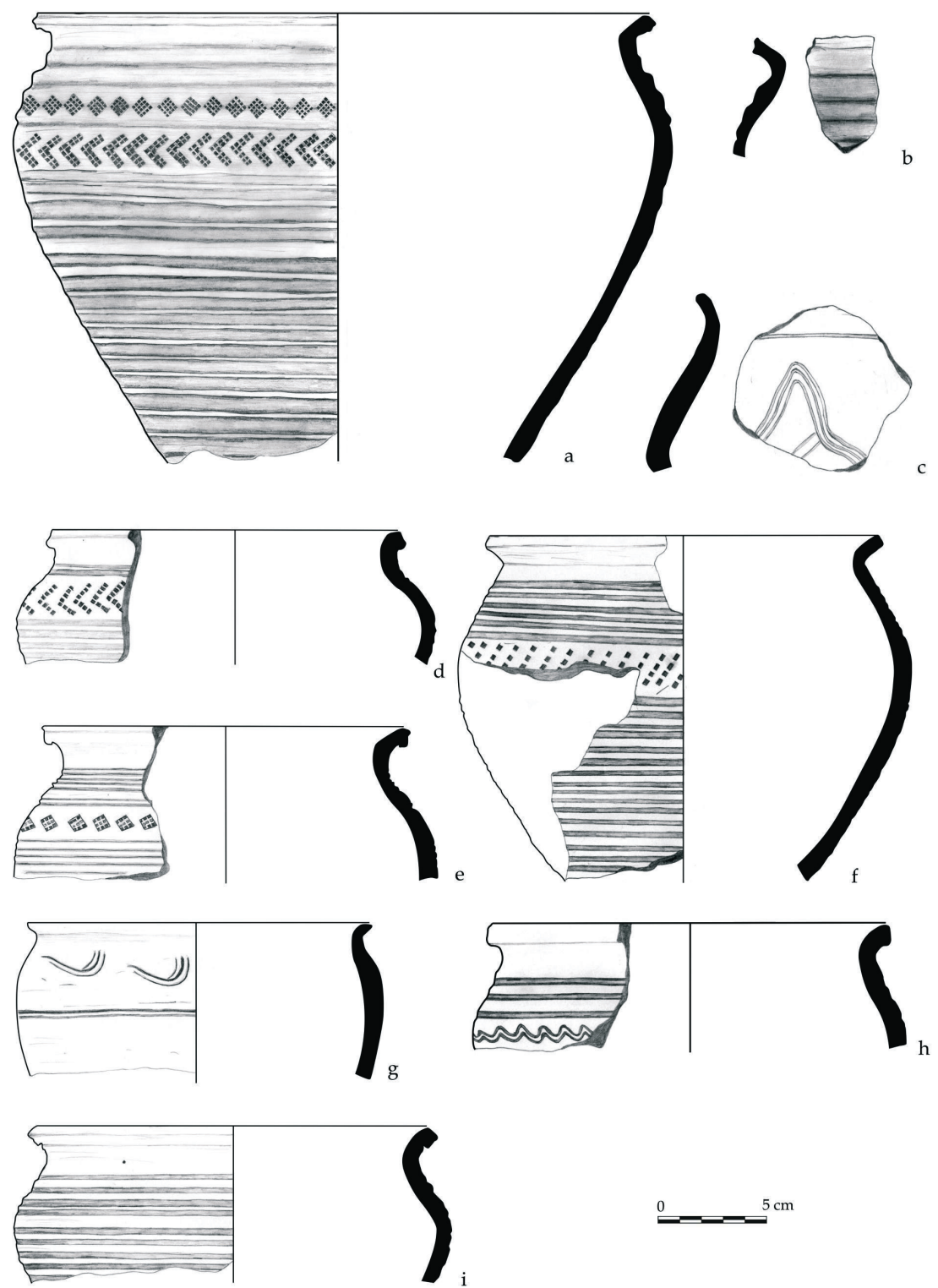

Ryc. 17. Ornowo-Lesiak, gm. Ostróda, stanowisko 3, wykop 1/2012. Naczynia ceramiczne z ziemianki (obiekt 2: a, b, e), obiektu z konstrukcją kamienną (obiekt 3: d, g-i) oraz warstwy 31 (c): a, b, d-f, h, i-GT V; c, g-GT III (rys. S. Wadyl)

Fig. 17. Ornowo-Lesiak, comm. Ostróda, site 3, trench 1/2012. Pottery from pithouse (feature 2: a, b,e), feature with the stone construction (feature 3: $\mathrm{d}, \mathrm{g}-\mathrm{i}$ ), and layer 31 (c): a, b, d-f, h, i-GT V; c, g- GT III (drawn by S. Wadyl) 


\section{Chronologia stanowisk}

Przeprowadzona analiza, a także prześledzenie związków chronologicznych ceramiki z mezoregionu górnej Drwęcy pozwoliła na poczynienie pewnych ustaleń odnoszących się do chronologii zbiorów pochodzących z poszczególnych zespołów osadniczych i stanowisk. Dała tym samym podstawy datowania procesów zasiedlenia dorzecza górnej Drwęcy.

W dotychczasowej literaturze grodzisko w Ornowie-Lesiaku datowano w szerokich ramach od IX do XII wieku (Mirkowska 2004; por. też Hoffmann, Mackiewicz 2004, s. 16). Dotychczas przyjmowano tezę o trzech fazach zasiedlenia tego obiektu, jednak wyniki badań archeologicznych przeprowadzonych w latach 2011-2012 skłaniają do innej interpretacji (szerzej na ten temat - por. Wadyl w druku a). Na obecnym etapie rozpoznania należy przyjąć istnienie tylko jednej fazy osadniczej, w związku z tym zespoły ceramiczne z grodziska w Ornowie-Lesiaku można uznać za homogeniczne. Przeważa w nich materiał całkowicie obtaczany (GT V - 86,5\%) nad przykrawędnie obtaczanym (GT II - 7,2\%) oraz obtaczanym do największej wydętości brzuśca (GT III - 9\%). Egzemplarze częściowo obtaczane można synchronizować z fazą IIIa rozwoju garncarstwa na ziemi chełmińskiej, z kolei całkowicie obtaczane z podfazą IIIb ${ }_{1}$ dla tego terenu (Chudziak 1991, s. 140) czy też fazą II rozwoju garncarstwa na ziemi lubawskiej (Grążawski 2009, s. 45-46). Dla większości naczyń można wskazać odpowiedniki na obszarach sąsiednich, ale także bardziej oddalonych od dorzecza górnej Drwęcy. Nie ma jednak ścisłych analogii dla części bogato zdobionych wyrobów o esowato uformowanych brzuścach. Najbliższe podobieństwa widoczne są w materiale z grodziska w Domkowie (stanowisko 1), oddalonym o koło 10 $\mathrm{km}$ na południe. Chronologię grodziska w Ornowie-Lesiaku można zawęzić do okresu od ostatnich dekad X do połowy(?) XI wieku.

Z grodziska w Domkowie (z bruku kamiennego) pochodzi nieliczny materiał ceramiczny, jednak o znacznej wartości poznawczej umożliwiającej datowanie obiektu. Przeważają w nim egzemplarze całkowicie obtaczane (GT $\mathrm{V}-55 \%$ ), esowate, nawiązujące do naczyń typu G/Vipperow, do których najbliższe analogie znane są z grodziska w Ornowie-Lesiaku. Pozostałą część zespołu stanowią naczynia częściowo obtaczane (GT II-III). Materiał ten pozwala datować powstanie obiektu w Domkowie na przełom X i XI do XI wieku. Na obecnym etapie rozpoznania grodziska nie jest możliwe określenie czasu wzniesienia umocnień w postaci potężnych wałów obronnych. Chrono- 
logię pobliskiej osady przygrodowej, ze względu na charakter pochodzącego z niej materiału ceramicznego (pozyskany w trakcie badań powierzchniowych), można określić jedynie w przybliżeniu na okres od końca IX do początku XI wieku.

Z grodzisk w Lipowcu i Morlinach pozyskano bardzo nieliczne zbiory ceramiczne. Ich struktura pozwala jedynie w przybliżeniu datować te obiekty na XI-XII wiek.

\section{Literatura}

Chudziak W.

1991 Periodyzacja rozwoju wczesnośredniowiecznej ceramiki z dorzecza dolnej Drwęcy (VII-XI/XII w.). Podstawy chronologii procesów zasiedlenia, Torun.

Chudziak W., Poliński D., Moszczyński A.

1997 Schemat analizy opisowej wczesnośredniowiecznej ceramiki naczyniowej, [w:] Wczesnośredniowieczny szlak lądowy z Kujaw do Prus (XI wiek). Studia i materiaty, red. W. Chudziak, Toruń, s. 231-243.

Curta F.

2006 The making of Slavs. History and archaeology of the Lower Danube Region c. 500-700, Cambridge.

Dulinicz M.

2001 Kształtowanie się Stowiańszczyzny Pótnocno-Zachodniej. Studium archeologiczne, Warszawa.

Grążawski K.

2009 Ziemia lubawska na pograniczu słowiańsko-pruskim w VIII-XIII w. Studium nad rozwojem osadnictwa, Olsztyn.

Hoffmann M., Mackiewicz A.

2004 Średniowieczne założenia obronne powiatu ostródzkiego, Ostróda.

Łosiński W.

1996 Menkendorf, [w:] Stownik Starożytności Stowiańskich, t. 8: Suplement $i$ indeksy, cz. 2: Supplement A-Ż, red. A. Gąsiorowski, G. Labuda, A. Wędzki, Wrocław, s. 435-439.

Łosiński W., Rogosz R.

1983 Zasady klasyfikacji i schemat taksonomiczny ceramiki, [w:] Szczecin we wczesnym średniowieczu. Wzgórze zamkowe, red. E. Cnotliwy, L. Leciejewicz, W. Łosiński, Wrocław, s. 202-225.

Mirkowska I.

2004 Ceramika wczesnośredniowieczna z grodziska w Kajkowie (przysiółek Lesiak), d. pow. Ostróda, woj. warmińsko-mazurskie, [w:] Ceramika zachodniobałtyjska. Nowe źródła i interpretacje. Materiały z konferencji, Białystok 23-24 września 2002 roku, red. M. Karczewska, M. Karczewski, Białystok, s. 281-291. 
Parczewski M.

1988 Początki kultury wczesnostowiańskiej w Polsce. Krytyka i datowanie źródet archeologicznych, Wrocław.

Schuldt E.

1956 Die slawische Keramik in Mecklenburg, Berlin.

Stanisławski B.

2012 Garncarstwo wczesnośredniowiecznego Wolina, Wrocław.

Szymański W.

2000 Trudne problemy w poznawaniu starszych faz wczesnego średniowiecza na ziemiach polskich, [w:] Archeologia i prahistoria polska w ostatnim pótwieczu. Materiaty z konferencji Dorobek polskiej archeologii i prahistorii ostatniego pótwiecza w Puszczykowie koło Poznania (27-30 października 1997 r.), red. M. Kobusiewicz, S. Kurnatowski, Poznań, s. 353-379.

Wadyl S.

2013 Badania weryfikacyjno-sondażowe grodzisk wczesnośredniowiecznych w dorzeczu górnej Drwęcy (Domkowo, Lipowiec, Ornowo-Lesiak, Morliny), [w:] Grodziska Warmii i Mazur. Stan wiedzy i perspektywy badawcze, t. 1, red. Z. Kobyliński, Archaeologica Hereditas, t. 2, Warszawa, s. 109-124.

w druku a Grodzisko w Ornowie-Lesiaku w świetle wyników ostatnich badań archeologicznych, Pruthenia, t. 7.

Weinkauf $\mathrm{M}$.

2011 Ceramika naczyniowa jako źródło poznania procesów osadniczych w strefie chełmińsko-dobrzyńskiej w początku wczesnego średniowiecza (VII-IX wiek), maszynopis rozprawy doktorskiej w Instytucie Archeologii UMK, Toruń.

Wróblewski W., Nowakiewicz T.

2003 Ceramika, pruska” $i$,słowiańska” we wczesnośredniowiecznej Galindii, [w:] Stowianie i ich sasiedzi we wczesnym średniowieczu, red. M. Dulinicz, Warszawa-Lublin, s. 165-181.

\section{EARLY MEDIEVAL POTTERY FROM THE UPPER DRWĘCA MESOREGION}

\section{Summary}

The main objective of the paper was to present the results of a multi-faceted analysis of the Early Medieval pottery from the Upper Drwęca Mesoregion. Pottery, which is the subject of analysis was discovered during the verifying trial excavation conducted by the expedition of Institute of Archaeology Nicolaus Coper- 
nicus University on Early Medieval hill forts in Domkowo, Lipowiec, Morliny, and Ornowo-Lesiak.

The results of the analysis of the technical-technological, morphological, and stylistic aspects were presented. The analysis, as well as tracing analogies allowed to make certain hypothesis relating to the chronology of various assemblages collected during the carried out in settlement complexes, and sites. At the same time it also provided basis for dating the habitation of the Upper Drwęca basin.

Analysed pottery was basis for determining the chronology of particular sites. The chronology of the Ornowo-Lesiak hill fort, until yet dated widely to the period from 9th till 12th century, at present may be restricted to the period from the last decades of the 10th till the second half of 11th century. The hill fort in Domkowo should be probably dated back to the turn of 10th and 11th century. A small number of ceramic sources collected during excavation of Lipowiec and Morliny hill forts only allows conditional dating of these sites to 11-12th century.

Translated by Stawomir Wadyl

Adres do korespondencji:

Stawomir Wadyl

Instytut Archeologii

Uniwersytet Mikołaja Kopernika w Toruniu

ul. Szosa Bydgoska 44/48, 87-100 Toruń

slawomirwadyl@wp.pl 